\title{
The Impact of Workers' Remittances on Economic Growth: Panel Data Approach for Selected Country Group
}

\author{
Burçak Polat \\ Correspondence: Burçak Polat, Siirt University, Business and Economics Faculty, Department of Economics, Siirt, \\ Turkey.
}

Received: November 12, 2018

doi:10.11114/aef.v6i1.3838

\author{
Accepted: November 27, 2018 \\ Available online: December 5, 2018 \\ URL: https://doi.org/10.11114/aef.v6i1.3838
}

\begin{abstract}
Recent decade has witnessed the growing importance of remittances as a source of foreign income for many developing countries. Thus, as the value of remittances around the world increases, many researchers attempt to analyze the remittances' effects on economic performance. Yet, real effect of remittances on economic growth rate is still controversial issue in the literature. Therefore, main objective of this study is to analyze the linkage between economic growth rates and remittance inflows into eight largest recipient countries of the global remittances by employing panel data analysis for the period 1990-2015. Our findings reveal that there is no significant relationship between remittances and growth. Yet, the study has empirically proved that growth is positively associated with gross capital formations and GDP per capita while it is negatively related with inflation and openness index.
\end{abstract}

Keywords: remittances, economic growth, panel data, foreign income

JEL Codes: F20, F21, F22, F23

\section{Introduction}

Workers' remittances (repatriation of immigrant earnings) from overseas countries to home countries become one of the most important sources of financing capital in the developing countries. According to the World Bank Report (2006), worldwide remittances flows accounted for $\$ 68$ billion in 1990, but total remittances have been increased to $\$ 232$ billion in 2005. Furthermore, (World Bank, 2011a, 2011b) reported that "remittances now account for more than two and a half times the global level of Official Development Assistance (ODA)." As of today, workers' remittances constitute the important source of foreign income for developing countries. Lartey (2013, p. 1038) pointed out the importance of global remittances by noting that "they currently represent about one-third of total financial flows to the developing world". Thus, a series of recent studies started to pay attention to the impact of workers' remittances on receiving country's economic growth through capital accumulation or other mechanisms. On one side, some researchers have proved the evidence that high levels of remittances are associated with lower poverty and high growth rates (Adams and Page 2005; Acosta et al. 2008). Some other researchers argued that high level of remittances inflows lead to higher human capital investments and reduce fluctuations in consumptions and cause economy stability (Gupta, Patillo and Wagh 2009). Still some other studies have claimed that high level of remittances may enhance the underdeveloped financial system in developing countries by mitigating the credit constraints and thus affect capital accumulations and economic growth positively (Woodruff and Zenteno, 2007; Lartey, 2013).

On the other side, several studies have argued that large remittances inflows may be harmful for the recipient country in the long-run and cause lower levels of growth rates. The reason behind of their views is that high levels of remittances inflows may reduce the labor supply of receiving households (Amuedo-Dorantes and Pozo, 2006b; Hanson, 2005) or may appreciate the receiving country currency which is known as Dutch Disease phenomena (Amuedo-Dorantes and Pozo, 2004; Bourdet and Falck, 2006; Acosta et al.2008). Yet, a few studies have analyzed the direct relationship between remittances and economic growth. Furthermore, these studies have provided inconclusive results with regard to the real impact of remittances on economic performance of recipient country. Thus main purpose of this study is to analyze the relationship between remittances and economic growth in eight countries that receive the highest portion of total remittances inflows in all over the world by employing Two Leas Square Instrumental Variable (2LS IV) method of panel data analysis. The countries in the analysis can be written namely as follows: Bangladesh, China, Egypt Arab Republic, India, Mexico, Nigeria, Pakistan, Philippines. Contribution of the study to the existing literature is three folds: 
First, contrary to previous studies, this study employs three panel data techniques to ensure the robustness of our estimates. We first start employing 2SLS IV technique to capture, if any, the endogeneity among growth and remittances. Later on, we employ FE and RE techniques to compare the test results with 2SLS IV panel data technique. After all, we choose the best-fit specification among all based on test statistics and their post estimations to interpret empirical results. Second, we have conducted the study for the countries that are grouped as developing or least developed countries by World Bank that receive the largest portion of remittances flows in the world. Third, by employing appropriate technique, we are able to find out if remittances have a role in shaping economic performance of those countries and to predict other determinants of economic growth in this country group.

The rest of the paper is organized as follows: Following introduction part, second section discusses the previous related works and their findings. Third section explains data and methodological part. Fourth section presents empirical findings. Finally, last section concludes the study.

\section{Literature Review}

An analysis of recent literature regarding the linkage between remittances and economic growth exposes that the real effect of remittances on economic growth is ambiguous and findings are still inconclusive. Some of literature has supported the positive linkage between economic growth and remittances, some others have claimed a negative linkage between two variables and still others found no relation at all. Regarding the economic growth process is a full of complexity so that the net effect of remittances on economic growth depends on the impact of remittances on different macroeconomic indicators such as investments (capital accumulations), real exchange rate, labor

supply of receiving households and financial developments of recipient country. Dissenting findings reveal that on one side, remittances may have adverse effects on economic growth through distorting the recipient families work incentives or appreciating of real exchange rate of recipient country. On the other side, remittances may serve as a tool to finance physical capital investments or human capital investments which in turn would contribute the positively to economic growth. Furthermore, even if remittances go toward consumption rather than investments, they help to smooth the volatility in consumption and contribute to the growth by stabilizing the economy.

Even though most of the literature supports the positive link between growth and remittances, some of the studies have found negative, conflicting or no relation between these two variables. For-example, the studies of Chami et al. (2005), Barajas et al. (2009), Roa and Hassan (2011) have found negative relationship or no relationship at all between economic growth rates and remittances. Furthermore, the study of Ruiz et al. (2009) has found a conflicting result by analyzing the relationship between growth rates and remittances by assuming the relationship between growth and remittances as non-linear rather than linear. They have proved a positive linkage between economic growth and remittances when they assume that contribution of remittances flows to growth linear, but such relationship disappears when non-linearity is taken account. Another study by Senbeta (2013) has found inconclusive evidence regarding the effect of remittances on economic growth. She has tried to find out the source of growth through the transmission mechanism instead of examining the impact of remittances on growth. Finally, she concluded that, while remittances affect the capital accumulations positively, inefficiency of investments reduces the total factor productivity (TFP) so that the real impact of remittances on growth remains ambiguous. Furthermore, a recent study by Dahal (2014) has analyzed the effect of remittances on economic growth in Nepal. He concluded that remittances are positively correlated with financial development and human capital accumulation but negatively correlated with international trade. Thus, he claimed that the effect of remittances on economic growth in Nepal is ambiguous.

On the other side, positive linkage between remittances and economic growth has been widely proved in the literature. For-example, Mundaca (2005) has found positive effects of remittances on economic growth and claimed that financial market development may boost the long-run contributions of remittances on economic growth. Moreover, Siddique et al. (2012) have analyzed the causality between growth and remittances in Bangladesh, India and Sri-Lanka. At the end of the study, they have found one-way causality running from remittances to growth in Bangladesh and two-way causality running from remittances to growth and from growth to remittances in Sri-Lanka. Moreover, the study by Lartey (2013) has investigated the relationship between economic growth and remittances flows into 36 Sub-Saharan African countries and found that remittances boost the economic growth but the contribution of remittances to growth increase as the level of financial development rises. Furthermore, the study of Feeny et al. (2014) has examined the link between remittances and economic growth in 136 developing countries including Small Island Developing States (SIDS) for the period 1971-2010. They have concluded that remittances flow to developed countries have no role in shaping economic performance of developed countries but, they affect growth rates in SIDS positively. They attributed the positive linkage between economic growth and remittances in SIDS to the role of remittances in reducing economic volatility and lead to favorable labor supply of recipient families. A recent study by Williams (2018) has examined whether the relationship between economic growth and remittances depends on the quality of democratic institutions for 109 developing countries for the period 1975-2014. He found out that remittances have a negative effect on growth in poor 
quality democratic institutions but the effect turns out to be positive as the democracy improves. He finally concluded that as democracy improves, recipient families are more likely to invest in human capital or invest small business activities which in turn would increase the growth rate of the economy. Moreover, a study has been conducted by Golitsis et al. (2018) has analyzed the impact of remittances and Foreign Direct Investments (FDI) on economic growth, inflation and gross fixed capital formation in Albania. At the end of the study, they have found one-way causality running from remittances flows to economic growth in both sort-run and long-run but failed to find any effect of remittances on gross-fixed capital formation.

\section{Data and Methodology}

\subsection{Data}

We have specified GDP growth rates as of our dependent variable. Alongside our main interest of variable (workers' remittances inflows), we have also incorporated additional control variables as follows: GDP per capita, Gross Capital Formation (domestic investment at constant prices of 2010), women labor participation rate of total labor force as proxy for human capital, high technological products exports as percentage of total manufacturing exports as an indicator of technological progress level, openness index calculated by taking the ratio of exports plus imports to the GDP and inflation. All variables are measured in US Dollars and obtained from World Bank Data retrieval tool (www.worldbank.org). Summary and descriptive statistics of data and expected signs of the coefficients are presented in Table 1.

Table 1. Summary and Discriptive Statistics

\begin{tabular}{lcccc}
\hline Variables & Observations & Mean & Standard Deviation & Expected Sign \\
\hline Growth (\%) & 208 & 5.3437 & 3.6059 & - \\
Remittances & 208 & 1.2951 & 1.5844 & Undetermined \\
GDP per capita & 208 & 1.9617 & 2.3997 & Undetermined \\
Gross Capital Formation & 208 & 272.2484 & 671.242 & Positive \\
Human Capital (\%) & 208 & 31.2574 & 9.8232 & Positive \\
Technology (\%) & 208 & 12.9125 & 19.2066 & Positive \\
Openness index & 208 & 48.0131 & 19.2942 & Undetermined \\
Inflation (\%) & 208 & 9.7838 & 12.8244 & Negative \\
\hline
\end{tabular}

As seen from Table 1, we don't have any missing observations in our dataset. Furthermore, one may easily observe from standard deviations that gross capital formation variable (domestic investments) at constant prices is the most volatile variable. Meaning that, those countries in the analysis have different amounts of investment level. Conversely, countries are close each other in terms of technological progress and the trade openness to the rest of the world. Furthermore, remittance inflow is the least volatile variable. In other words, flows of remittances into these countries show a stable pattern.

Prior to our empirical estimations, we have carried on Fisher type Augmented Dickey Fuller test for each variable in the analysis to find out if they are stationary or not. We have tested null hypothesis $H_{0}=$ all panels include unit root over alternative hypothesis, $H_{1}=$ all panels do not include unit root. The results of panel Fisher type panel data unit root test are provided in Table 2.

Table 2. Fisher-Type Unit Root Test Results

\begin{tabular}{lcc}
\hline Variables & Augmented Dickey Fuller Test & $\begin{array}{c}\text { Augmented Dickey Fuller } \\
\text { Test (First Differences) }\end{array}$ \\
\hline Growth & 12.1120 & - \\
Remittances & $(0.000)^{* *}$ & 16.168 \\
& -2.7508 & $(0.000)^{* *}$ \\
GDP per capita & $(0.9970)$ & 11.8597 \\
Gross Capital Formation & -2.5737 & $(0.000)^{* *}$ \\
Human Capital & $(0.9950)$ & 17.6151 \\
& -2.6962 & $(0.000)^{* *}$ \\
Technology & $(0.9965)$ & 13.6818 \\
& -2.2178 & $(0.000)^{* *}$ \\
Openness & $(0.9867)$ & - \\
Inflation & 7.3657 & 24.4123 \\
\hline
\end{tabular}


$(0.000)^{* * *}$

Note: Probability values of test statistics are provided in the paranthesis

As one may easily observe from the first column of Table 2, we can' reject the null hypothesis so that we conclude that all variables include unit roots at their levels except inflation, GDP growth rate and technology variables. Thus, we have taken the first difference of those variables (Remittances, GDP per capita, Gross Capital Formation, Human Capital and Openness) that are not stationary at their levels. Then, we repeat the Augmented Dickey Fuller Test once more and labeled it in the second column of Table 2 . As one may easily see from probability values, all variables which were non-stationary at their level form converted to be stationary at their first differences.

\subsection{Methodology}

\subsubsection{Panel Data Models, Instrumental Variables (IV) and 2SLS IV}

Panel data models provide information on individual behavior both across individuals and over time. The data and models have both cross-sectional and time-series dimensions. Panel data model simply can be shown as:

$$
Y_{i, t}=\beta_{0}+\sum_{i,=1}^{N} X_{i, t}+\alpha_{i}+\varepsilon_{i, t}
$$

$Y_{i, t}$ represents dependent variable with i and t subscriptions indicating cross sections (individuals) and time periods

respectively. Furthermore, while $\sum_{i,=1}^{N} X_{i, t}$ indicates explanatory variables, $\alpha_{i}$ and $\varepsilon_{i, t}$ represent individual fixed effect that is time invariant and time variant error term respectively. There are two types of panel data models. These are short-panel data models and long panel data models. While short panel data models are associated with few time periods $(\mathrm{T})$ and many individuals $(\mathrm{N})$, conversely, long panel data models are associated with many time periods for a relatively few individuals. The main distinction of long panel data models from short panel data models is that one may control individual fixed effect $\left(\alpha_{i}\right)$ by including dummy variables for each individual as regressors. In other words, when the panel has few individuals relatively to the number of periods, the individual effects $\left(\alpha_{i}\right)$ can be incorporated into the $X_{i t}$ as dummy variable regressor. Since, there are too many time effects rather than individual effects $\left(\alpha_{i}\right)$, one should control for time effect rather than individual effects in the long-panel data models. Furthermore, Fixed Effect (FE) or Random Effect (RE) panel data techniques can be employed in both short-panel data and long-panel data models to produce consistent estimates that do not violate Ordinary Least Square (OLS) assumptions.

However, if panel data specification includes endogenous variable, both FE and RE become inappropriate techniques to produce unbiased estimators. In such case, one should use Instrumental Variables (IV) to eliminate individual effect which may be correlated with explanatory variables. In other words, employing IV is a necessity when model specification includes endogenous variables. That is where $\operatorname{Cov}(X, \varepsilon) \neq 0$ and violates the assumption of OLS. Our long-panel data model incorporates IV as workers' remittance variable is an endogenous variable and can be correlated with growth simultaneously. In order for a variable, $\mathrm{z}$, to serve as a valid instrument for $\mathrm{x}$ (endogenous variable), the following must be true:

First, the instrumental variable must be exogenous that is $\operatorname{Cov}(z, \varepsilon)=0$. Second, instrumental variable (selected) must be correlated with endogenous variable (x), that is $\operatorname{Cov}(z, x) \neq 0$.

We can test if an instrumental variable selected is a valid instrument or not by testing null hypothesis $H_{0}=0$ in the regression, $x=\beta_{0}+\beta_{1} z+v$.

For-example, for a regression that includes instrumental variable, $Y=\beta_{0}+\beta_{1} x+u$

Based on our assumptions, we can show mathematically that instrumental variable can be a best-fit valid instrument only if it is correlated with endogenous variable.

$$
\begin{gathered}
\operatorname{Cov}(z, y)=\operatorname{Cov}\left(z, \beta_{0}+\beta_{1} x+u\right) \\
=\operatorname{Cov}\left(z, \beta_{0}\right)+\operatorname{Cov}\left(z, \beta_{1} x\right)+\operatorname{Cov}(z, u)
\end{gathered}
$$




$$
\begin{gathered}
=\beta_{1} \operatorname{Cov}(z, x)+\operatorname{Cov}(z, u) \\
=\beta_{1} \operatorname{Cov}(z, x) \\
\beta_{1}=\frac{\operatorname{Cov}(z, y)}{\operatorname{Cov}(z, x)}
\end{gathered}
$$

From this deviation, it is clearly seen that if $\operatorname{Cov}(z, x)=0, \beta_{1}$ is not well defined and $\mathrm{z}$ is not a best-fit instrumental variable.

As it sounds, 2STL IV model has two stages:

First stage is to isolates the part of $\mathrm{x}$ that is uncorrelated with error term $(u)$, than regress $\mathrm{x}$ (endogenous variable) on $\mathrm{z}$ (instrumental variable selected) by emplyoing OLS:

$x_{i}=\delta_{o}+\delta_{1} z_{i}+v_{i}$

Here, $z_{i}$ is uncorrelated with $v_{i}$ but correlated with $x_{i}$. After estimating the predicted value of $x_{i}$, where $\hat{x}_{i}=\hat{\delta}_{0}+\hat{\delta}_{1} z_{i} \quad i=1,2,3 \ldots \ldots \ldots \ldots \ldots \ldots, n$.

After estimating the predicted value of $\hat{x}_{i}$, one should replace $x_{i}$ by $\hat{x}_{i}$ in the regression of interest in the second stage, than regress $\mathrm{Y}$ on $\hat{x}_{i}$ by using OLS.

In the Second Stage, main regresion of interest can be shown as:

$$
Y_{i}=\beta_{0}+\beta_{1} \hat{x}_{i}+u_{i}
$$

As $\hat{x}_{i}$ is not correlated with error term $\left(u_{i}\right)$ (if $\mathrm{N}$ is large), the first Least Square Estimation holds. So that, At the second stage, $\beta_{1}$ can be estimated by using OLS and this resulting estimator is called 2STL IV estimator of $\hat{\beta}_{1}$.

\subsubsection{Model Specification}

Our orginal model to be tested can be shown as below:

$$
\text { Growth }_{i, t}=\beta_{0}+\sum_{i,=1}^{N=6} X_{i, t}+z_{i, t}+\alpha_{i}+\varepsilon_{i, t}
$$

Growth $_{i, t}$ represents economic growth as of our dependent variable for each country from 1990 to 2015. Furthermore,

while $\sum_{i=1}^{N=6} X_{i, t}$ indicates exogenous control variables incorporated into the three panel data specifications, $z_{i, t}$ represents endogenous variable, that is our main interest of variable, workers' remittances in each country. Moreover, $\alpha_{i}$ and

$\varepsilon_{i, t}$ indicate the individual fixed effect which is time invariant and time variant error term respectively.

Priority to estimating 2STL Tests, one should conduct Wu-Hausman Test (WH test) statistics to find out if there is a need to include instrumental variable or not. Davidson and MacKinnon (1993) have suggested an augmented regression test (DWH test), which can easily be performed by taking the residuals of endogenous variable, as a function of exogenous variables, in the original regression. If the residuals of endogenous variable are significant and different than zero, then OLS estimates become an inconsistent estimate which means that we should include instrumental variable in model specification. On the other side, if the residuals of endogenous variable incorporated into the main model specification is not significant, then there is no need to incorporate IV into the model. Based on our DWH test result, we have decided that workers' remittance variable is not endogenous and there is no need to include IV into the model. Thus, after dropping IV from our original panel data specification, our main model specification can be shown as follows: 


$$
\text { Growth }_{i, t}=\beta_{0}+\sum_{i,=1}^{N=7} X_{i, t}+\alpha_{i}+\varepsilon_{i, t}
$$

\section{Empirical Resulst}

To measure the effects of workers' remittances on economic performance of eight countries that receive the largest portion of remittances from outside of the home country for the period 1990-2015; we have first conducted DWH tests to determine if including IV is needed or not. Yet, failing to reject DWH test indicates that results of RE and 2SLS IV panel data specifications produce similar estimates and there is no need for IV in the regression. In any case, we have conducted 2SLS panel data teqnique alongside, RE and FE panel data tests statsitics and present their estimation results in Table 3. As seen from Table 3, DWH tests ensures that RE and 2SLS IV produce similar results while FE produces different results. Yet, failing to reject of Hausman test statistics proposed by Hausman (1978) indicates that RE is superior to FE as RE includes more information by keeping individual fixed effect in the regression.

Table 3. Estimation Results

\begin{tabular}{lccc}
\hline Variables & Random Effect & Fixed Effect & 2SLS IV \\
\hline Constant & 5.3749 & 5.6961 & 5.3096 \\
& $(0.000)^{* *}$ & $(0.000)^{* *}$ & $(0.000)^{* *}$ \\
Remittances & 1.3324 & 1.0149 & 0.0001 \\
& $(0.138)$ & $(0.225)$ & $(0.333)$ \\
GDP per capita & 1.7078 & 2.8543 & 1.6476 \\
Gross Capital Formation & $(0.019)^{* *}$ & $(0.000)^{* *}$ & $(0.025)^{*}$ \\
Human Capital & 0.0174 & -0.0031 & 0.0169 \\
& $(0.000)^{* *}$ & $(0.537)$ & $(0.000)^{* *}$ \\
Technology & -0.0112 & 0.7425 & 0.0525 \\
& $(0.985)$ & $(0.197)$ & $(0.930)$ \\
Openness & -0.0212 & -0.0187 & -0.0216 \\
& $(0.072)$ & $(0.570)$ & $(0.062)$ \\
Inflation & -0.0744 & -0.0640 & -0.0775 \\
& $(0.053)^{*}$ & $(0.070)$ & $(0.045)^{*}$ \\
Dummy for 2008 & -0.0535 & -0.0582 & $(0.0535$ \\
Dummy for 2009 & $(0.003)^{* *}$ & $(0.001)^{* *}$ & -0.2969 \\
Hausman Test Statistics & -0.6129 & -0.5561 & $(0.549)$ \\
Wu-Hausman F(1, 186) Test & $(0.596)$ & $(0.624)$ & -15021 \\
& -1.6330 & -0.1569 & $(0.239)$ \\
\end{tabular}

Note: $* *$ refers to $\% 1$ significance level while $*$ refers to $\% 5$ significance level. Probability values of standard errors are provided in the phranthesis.

Turning back to the resulst of RE or 2SLS IV test statistics, we can not find evidicence supporting the existance of any linkage between workers' remittances and economic growth for the selected country group. Yet, we have emprically proved that while GDP per capita and Gross Capital Formation (gross capital investments) have positive and significant effect on economic growth; openess index and inflation variables have a negative and significant impact on economic performance of those countries.

Empirical Findings can be interpreted as follows: An increase in GDP per capita boosts economic growth of the country group in the analysis. This result does not come a surprise, as GDP per capita increases, households consumpiton and saving levels increase as well. So that, investors are likley to be motivated to produce more goods and services in order to meet domestic demand in the market. As an natural outcome, we may expect that a higher GDP per capita will lead to increase in GDP growth rate. From a similar perspective, higher Gross Capital Formation (higher amount of gross investments) is likely to rise economic growth. It is the mere fact that, production capacity of firms heavily depends on the amounts investments on physical capital products. Thus, as firms increase the amount of investments on physical capital products, they are more likely to increase the production capacity and thus, cause an increase in growth rate of the economy.

On the other side, an increase in openness index or inflation affects growth rates negatively and deteriorates the economic performance. The negative impact of openness index and inflation can be explained as follows: First, the countries in the analysis are mostly least developed markets so that economic performance of those countries heavily depends on import products rather than export products. Since industrialization process of those countries are still 
incomplete, production capacity of those countries is constrained to the imported intermediate products. Therefore, one may easily assume that as these countries become more open to the rest of the world, they are likely to increase the amounts of imports rather than amounts of exports. So that, as the involvement level of those countries in the international market increases, economic performance of those countries is likely to decrease. Furthermore, inflation rate is one of the most important indicators of economic performance of both developed and developing countries. Higher inflation rates are likely to inflate the input prices for production and then cause investors to reduce their production of goods and services. Thus, a decline in GDP due to the higher input prices may cost lower economic growth rates.

Lastly, We could not find any effect of other control variables (Human Capital and Technological Progress) on the economic growth rates. Additionally, although most of the developed and developing countries have beeen affected severly from the Global Financial Crisis(GFC) that occurred in USA in the year of 2008 and 2009, we could not find any evidence supporting the deteriorating effects of GFC on economic growth rates of those countries in the analysis.

\section{Summary and Conluding Remarks}

Recent decade has witnessed the growing importance of remittances as an important source of foreign income for many developing countries. Thus, the increase in the value of remittances around the world lead to many researchers to attempt finding the impact of remittances on economic growth through gross capital formations (investments) or any other mechanisms. Yet, direct effect of remittances on economic growth rate is still a controversial and inconclusive issue in the literature. Therefore, this study attempts to fill the gap in the literature by analyzing the linkage between economic growth rates and remittance inflows into eight countries receiving the largest portion of the global remittances flows all over the world.

Novelty of the paper can be expressed as follows: First, this study employs 2SLS IV technique of panel data method to capture endogeneity, if any, among remittances and economic growth. Second, we have employed additional FE and RE panel data techniques to choose the best-fit specifications among all to interpret the results. Third, study conducts the analysis for eight countries that receive the largest portion of global remittances in the world.

At the end of the study, we could not find any evidence supporting a positive link between economic growth and remittances. As proposed by Williams (2018), institutional factors such as democracy or human right may be affecting the decision of families receiving remittances to invest in human capital or small business activities. Since the countries in the analysis are least developed countries with poor institutional indicators such as democracy or human rights, remittances may not be directed to the human capital investments or any other small business investments. Thus, repatriated earnings of migrants to their families may be used a tool for risk sharing mechanism or for survival of poor families in those countries. On the other side, we have proved empirically that economic growth is positively linked with gross capital formations (investments) and GDP per capita while it is negatively related with openness index and inflation.

Policy implications from our results are worthy to note: Countries in the analysis should improve the quality of institutional factors such as democracy or human rights to motivate families of migrants to direct their savings including remittances to the human capital investments and small family businesses which in turn would affect economic growth positively. Second, financial systems in those countries should be improved to facilitate the transferring of remittances from overseas countries to home countries. We believe in that well-developed financial system will reduce the transaction costs of repatriations and then will increase the contributions of remittances to the economic growth.

\section{References}

Acosta, P., Calderon, C., Fajnzylber, P., \& Lopez, H. (2008). What is the impact of international migrant remittances on poverty and inequality in Latin America? World Development, 36(1), 89-114. https://doi.org/10.1016/j.worlddev.2007.02.016

Adams, R., \& Page, J. (2005). Do international migration and remittances reduce poverty in developing countries? World Development, 33(10): 1645-69. https://doi.org/10.1016/j.worlddev.2005.05.004

Amuedo-Dorantes, C., \& Pozo, S. (2004). Workers' remittances and the real exchange rate: A paradox of gifts. World Development, 32(8), 1407-17. https://doi.org/10.1016/j.worlddev.2004.02.004

Amuedo-Dorantes, C., \& Pozo, S. (2006b). Migration, remittances and male and female employment patterns, American Economic Review, 96(2), 222-226. https://doi.org/10.1257/000282806777211946

Barajas, A., Chami, R., Fullenkamp, C., Gapen, M., \& Montiel, P. (2009). Do workers' remittances promote growth? IMF Working Paper 153.

Bourdet, Y., \& Falck, H. (2006). Emigrants' remittances and Dutch disease in Cape Verde. International Economic Journal, 20(3), 267-284. https://doi.org/10.1080/10168730600879323 
Chami, R., Fullenkamp, C., \& Jahjah, S. (2005). Are immigrant remittance flows a source of capital for development, IMF Staff Papers, 52, 55-81.

Dahal, P. (2014). The impact of remittances on economic growth in Nepal: An analysis of a significant basis of development. Asia Pacific Journal of Public Administration, 36(4), 261-282. https://doi.org/10.1080/23276665.2014.975908

Davidson, R., \& Mackinnon, J. G. (1993). Estimation and inference in econometrics, Journal of Applied Econometrics, $10,339-341$.

Feeny, S., Lamsiraroj, S., \& McGillivray, M. (2014). Remittances and economic growth: Larger impacts in smaller countries? The Journal of Development Studies, 50(8), 1055-1066. https://doi.org/10.1080/00220388.2014.895815

Golitsis, P., Avdiu, K., \& Szamosi, L. T. (2018). Remittances and FDI effects on economic growth: A VECM and GIRFs for the case of Albania. Journal of East-West Business. https://doi.org/10.1080/10669868.2018.1435432

Gupta, S., Pattillo, C. A., \& Wagh, S. (2009). Effect of remittances on poverty and financial development in Sub-Saharan Africa. World Development, 37(1), 104-15. https://doi.org/10.1016/j.worlddev.2008.05.007

Hanson, G. (2005). Emigration, labor supply, and earnings in Mexico. NBER Working Paperi 11412.

Hausman, J. A. (1978). Specification tests in econometrics. Econometrica, 46(6), 1251-1271. https://doi.org/10.2307/1913827

Lartey, E. K. K. (2013). Remittances, investment and growth in sub-Saharan Africa. The Journal of International Trade \& Economic development, 22(7), 1038-58. https://doi.org/10.1080/09638199.2011.632692

Mundaca, G. B. (2005). Can remittances enhance economic growth? The role of financial markets development. Mimeo, University of Oslo.

Rao, B. B., \& Hassan, G. M. (2011). A panel data analysis of the growth effects of remittances. Economic Modelling, 28, 701-709. https://doi.org/10.1016/j.econmod.2010.05.011

Ruiz, I., Shukralla, E., \& Vargas-Silva, C. (2009). Remittances, institutions and growth: A semiparametric study. International Economic Journal, 23(1), 111-119. https://doi.org/10.1080/10168730802696715

Senbeta, A. (2013). Remittances and the source of growth. Applied Economics Letters, 20(6), 572-580. https://doi.org/10.1080/13504851.2012.718057

Siddique, A., Selvanathan, E. A., \& Selvanathan, S. (2012). Remittances and economic growth: Empirical evidence from Bangladesh, India, and Sri Lanka. Journal of Development Studies, 48(8), 1045-1062. https://doi.org/10.1080/00220388.2012.663904

Williams, K. (2018). Are remittances good for economic growth? The role of political institutions. Applied Economics Letters, 25(1), 56-60. https://doi.org/10.1080/13504851.2017.1293781

Woodruff, C., \& Zenteno, R. (2007). Migration networks and microenterprises in Mexico. Journal of Development Economics, 82, 509-528. https://doi.org/10.1016/j.jdeveco.2006.03.006

World Bank (2006). Global Economic Prospects: Economic Implications of Remittances and Migration. Washington D.C.: World Bank

World Bank (2011a). Migration and development brief 17. Migration and remittances unit, development economics (DEC) and poverty reduction and economic management (PREM). Washington, D.C.: World Bank.

World Bank (2011b). World development indicators online database. Washington, D.C.: World Bank.

\section{Copyrights}

Copyright for this article is retained by the author(s), with first publication rights granted to the journal.

This is an open-access article distributed under the terms and conditions of the Creative Commons Attribution license which permits unrestricted use, distribution, and reproduction in any medium, provided the original work is properly cited. 